\title{
KURVA PHILLIPS DI INDONESIA
}

\author{
Maichal \\ Faculty of Entrepreneurial Business Universitas Ciputra \\ UC Town, CitraLand Surabaya 60219 \\ E-mail: maichal@ciputra.ac.id
}

Diterima 30 April 2012/ Disetujui 4 September 2012

\begin{abstract}
This paper aims to analyze the existence of the Phillips curve in the Indonesian economy, 2000Q1-2010Q3. The results obtained by using OLS method shows that the expectationss augmented Phillips curve and the New Keynesian Phillips curve models cannot give a clear results of Phillips curve existence in the Indonesia economy. Shocks variable such as percentage change of exchange rates and crude oil prices provide a very small effect on the inflation rate in Indonesia. Furthermore, the results obtained by using GMM method on the hybrid model of the New Keynesian Phillips curve shows that the Phillips curve exists in the Indonesian economy.
\end{abstract}

Keywords: phillips curve, hybrid model, new keynesian phillips curve

\begin{abstract}
Abstrak: Paper ini bertujuan menganalisis eksistensi fenomena kurva Phillips di perekonomian Indonesia, 2000Q1-2010Q3. Hasil penaksiran yang diperoleh dengan menggunakan metode OLS menunjukkan bahwa model expectationss augmented Phillips curve dan new Keynesian Phillips curve tidak dapat memberikan gambaran yang jelas mengenai eksistensi kurva Phillips di perekonomian Indonesia. Variabel guncangan seperti persentase perubahan kurs dan harga minyak mentah memberikan pengaruh yang sangat kecil terhadap tingkat inflasi di Indonesia. Selanjutnya, hasil penaksiran dengan menggunakan metode GMM pada hybrid model dari new Keynesian Phillips curve menunjukkan bahwa fenomena kurva Phillips eksis di perekonomian Indonesia.
\end{abstract}

Kata kunci: kurva phillips, hybrid model, new keynesian phillips curve

\section{PENDAHULUAN}

Kebijakan ekonomi yang dilakukan oleh setiap negara secara umum ditujukan untuk mencapai tingkat pengangguran yang rendah (high employment), stabilitas harga (stable price) dan pertumbuhan ekonomi yang tinggi (rapid growth) (Friedman, 1968). Dalam penerapannya, kebijakan ekonomi terbagi menjadi dua jenis, yaitu kebijakan fiskal dan kebijakan moneter.

Secara teoritis, kebijakan moneter digunakan oleh bank sentral dalam jangka pendek untuk mencapai dua sasaran, yaitu untuk menjaga aktivitas ekonomi tetap tinggi dan mencapai tingkat inflasi yang rendah (Dornbusch, et al, 2008). Fakta empiris menunjukkan bahwa terdapat tradeoff antara kedua sasaran tersebut, di mana meningkatnya pertumbuhan output (atau penurunan tingkat pengangguran) cenderung diikuti oleh meningkatnya tingkat inflasi. Tradeoff antara tingkat pengangguran dan tingkat inflasi pertama kali ditunjukkan oleh Phillips (1958) pada perekonomian Inggris, 1861-1957.

Studi empiris mengenai tradeoff antara tingkat inflasi dan tingkat pengangguran kemudian dikembangkan oleh Samuelson dan Solow (1960) yang juga menemukan adanya korelasi negatif antara tingkat inflasi dan tingkat pengangguran di Amerika Serikat.

Perkembangan lebih lanjut mengenai fenomena kurva Phillips dikemukakan oleh Friedman (1968) dan Phelps (1968) yang berpendapat bahwa tradeoff antara tingkat inflasi dan tingkat pengangguran hanya akan terjadi dalam jangka 
pendek. Sedangkan, dalam jangka panjang, tradeoff tidak akan terjadi karena dalam jangka panjang, para pembuat kebijakan moneter akan menghadapi kurva Phillips yang vertikal, di mana tingkat pengangguran cenderung berada pada tingkat alamiahnya, sehingga kebijakan moneter yang berlaku hanya akan mempengaruhi tingkat inflasi.

Fakta empiris yang mendukung pendapat Friedman dan Phelps adalah stagflasi yang dialami oleh negara-negara industri pada tahun 1970-an. Stagflasi ini bertolak belakang dengan hubungan negatif yang ditunjukkan oleh kurva Phillips dan menunjukkan bahwa dalam jangka panjang, tradeoff pada kurva Phillips tidak akan terjadi (Solikin, 2004). Stagflasi ini sekaligus menjadi penyebab keruntuhan kurva Phillips di era 1970an dan 1980an (Case dan Fair, 2007).

Model makroekonomi terbaru yang dikembangkan oleh ekonom New Keynesian, kurva Phillips kini menunjukkan korelasi positif antara tingkat inflasi dan tingkat output (Roberts, 1995; Gali dan Gertler, 1999; Clarida et. al, 1999). Hubungan antara tingkat inflasi dan tingkat output kemudian disebut New Keynesian Phillips Curve (NKPC).

Perkembangan yang lebih lanjut, model New Keynesian Phillips Curve mendapat beberapa kritik (Ball, 1994a, 1994b; Fuhrer dan Moore, 1995) yang menunjukkan bahwa model tersebut tidak optimal untuk menganalisis fenomena kurva Phillips. Terkait dengan kritik-kritik tersebut, Gali dan Gertler (1999) mengembangkan suatu hybrid model dari New Keynesian Phillips Curve, yaitu sebuah model yang memasukkan efek kelambanan inflasi dengan memasukan tingkat inflasi secara backward-looking sebagai rule of thumb dalam menentukan harga.

Studi empiris mengenai kurva Phillips di Indonesia menunjukkan hasil yang berbedabeda. Penelitian yang menggunakan model kurva Phillips sederhana (expectations augmented Phillips curve) menyimpulkan bahwa fenomena kurva Phillips tidak eksis di perekonomian Indonesia (lihat, Amir, 2008; Sri Mulyati, 2009; Puzon, 2009) ${ }^{1}$. Beberapa penelitian lain yang menggunakan model kurva Phillips sederhana menyimpulkan bahwa fenomena kurva Phillips

1 Alat analisis yang digunakan oleh para penulis adalah dengan menggunakan metode Ordinary Least Square (OLS) eksis di perekonomian Indonesia (Ika A.P, 2008) $)^{2}$.

Studi empiris lainnya yang telah menggunakan NKPC dan hybrid model dari NKPC menyimpulkan bahwa fenomena kurva Phillips eksis di perekonomian Indonesia (Solikin, 2004; Sarwohadi, 2009).

Hasil analisis yang diperoleh dari penelitian-penelitian terdahulu memberikan hasil yang berbeda-beda, di mana beberapa penelitian menyatakan bahwa kurva Phillips tidak eksis dan beberapa penelitian lainnya menyatakan bahwa kurva Phillips eksis di perekonomian Indonesia. Dengan demikian, hasil analisis mana yang harus diambil sebagai kesimpulan akhir.

Selain itu, estimasi model pada penelitianpenelitian yang telah menggunakan NKPC maupun hybrid model dari NKPC belum memasukkan variabel guncangan seperti perubahan nilai tukar dan perubahan harga minyak dunia. Variabel guncangan menjadi penting dalam penaksiran model kurva Phillips karena stagflasi yang terjadi pada tahun 1970-an di Amerika Serikat dan negara-negara industri lainnya yang pada akhirnya menyebabkan runtuhnya fenomena kurva Phillips, secara umum disebabkan akibat adanya kenaikan harga minyak dunia oleh OPEC. Oleh karena itu, variabel guncangan perlu dimasukkan ke dalam model kurva Phillips dengan tujuan untuk menggambarkan kemungkinan adanya pergeseran pada fenomena trade-off yang ditunjukkan oleh kurva Phillips (Ball dan Mankiw, 2002).

Untuk itu, paper ini bertujuan untuk menganalisis kembali eksistensi fenomena kurva Phillips di Indonesia, 2000Q1-2010Q3 dengan menggunakan model expectations augmented Phillips curve, NKPC dan hybrid model dari NKPC dengan memasukan variabel guncangan seperti perubahan nilai tukar dan harga minyak mentah dunia. Penelitian ini juga menggunakan beberapa indikator inflasi seperti inflasi Indeks Harga Konsumen (IHK), Deflator Produk Domestik Bruto (PDB), inflasi inti dan inflasi IHK y-o-y dengan tujuan untuk mengantisipasi kemungkinan adanya perbedaan hasil penak-

\footnotetext{
2 Hasil yang berbeda dikarenakan penulis menggunakan metode Error Correction Model (ECM).
} 
siran apabila data indikator inflasi yang digunakan berbeda.

\section{METODE PENELITIAN}

Data yang digunakan dalam penelitian ini adalah data time series secara kuartalan periode 2000Q1-2010Q3. Data yang digunakan bersumber dari Badan Pusat Statistik (BPS), Bank Indonesia (BI), International Financial Statistic (IFS) dan U.S Energy Information Administration (EIA). Data yang digunakan meliputi: (1) inflasi IHK y-o-y; (2) IHK (2007=100); (3) deflator PDB (2005=100); (4) inflasi inti (2007=100); (5) PDB atas dasar harga konstan 2000; (6) harga minyak mentah; (7) data variabel-variabel instrumental seperti pertumbuhan uang primer dan perubahan nilai tukar rupiah terhadap dolar AS.

Metode analisis yang digunakan dalam penelitian ini adalah dengan metode Ordinary Least Square (OLS) dan Generalized Method of Moments (GMM). Untuk mendapatkan hasil estimasi yang baik, maka penaksiran dengan metode OLS akan melalui tahap uji asumsi klasik. Adapun model yang digunakan dalam penelitian ini adalah sebagai berikut:

$$
\begin{aligned}
\pi_{i t}= & a+b_{1} \pi_{i t-1}+b_{2} \operatorname{lnygap}_{t}+b_{3} \Delta \text { kurs }_{t}+b_{4} \text { oil }_{t} \\
& +e_{t}
\end{aligned}
$$

di mana $\pi_{i t}$ adalah inflasi $i$ pada kuartal $t$; $a$ adalah konstanta; $b$ adalah koefisien parameter estimasi; $\pi_{i t-1}$ adalah tingkat inflasi $i$ secara backward-looking ( $t-1)$; lnygapt adalah logaritma natural output gap pada kuartal $t ; \Delta k u r s_{t}$ adalah perubahan nilai tukar pada kuartal $t$; oil $t_{t}$ adalah harga minyak mentah pada kuartal $t$ dan $e_{t}$ merupakan residual. Persamaan (1) merupakan model expectations augmented Phillips curve yang akan dianalisis dengan menggunakan metode OLS. Dalam penelitian ini, output gap diperoleh dengan menggunakan Hodrick-Prescott (HP) filter dengan koefisien smoothing $(\lambda)=1600$ untuk data kuartalan. Penaksiran dengan menggunakan model NKPC akan dianalisis dengan mengestimasi persamaan berikut:

$$
\begin{aligned}
\pi_{i t}= & a+r_{1} \pi_{i t+1}+r_{2} \operatorname{lnygap}{ }_{t}+r_{3} \Delta \text { kurs }_{t}+\gamma_{4} \text { oil }_{t} \\
& +e_{t}
\end{aligned}
$$

di mana, $\gamma$ adalah koefisien parameter estimasi; $\pi_{i t+1}$ adalah tingkat inflasi $i$ secara forwardlooking $(t+1)$. Model NKPC pada persamaan (2) juga akan dianalisis dengan metode OLS. Penaksiran dengan menggunakan hybrid model dari NKPC akan dianalisis dengan mengestimasi tiga persamaan berikut:

$$
\begin{aligned}
& \pi_{i t}=a+\delta_{1} \pi_{i t-1}+\delta_{2} \pi_{i t+1}+\delta_{3} \text { lnygap }_{t} \\
& +e_{t} \\
& \pi_{i t}=a+\delta_{1} \pi_{i t-1}+\delta_{2} \pi_{i t+1}+\delta_{3} \text { lnygap }_{t-1} \\
& +e_{t} \\
& \pi_{i t}=a+\delta_{1} \pi_{i t-1}+\delta_{2} \pi_{i t+1}+\delta_{3} \operatorname{lnygap}_{t+1} \\
& +e_{t}
\end{aligned}
$$

di mana, $\delta$ merupakan koefisien parameter estimasi; lnygap t-1 $_{\text {adalah logaritma natural output }}$ gap pada kuartal $t-1$; dan lnygap $_{t+1}$ adalah logaritma natural output gap

Berbeda dengan persamaan (1) dan (2), persamaan (3), (4) dan (5) akan di analisis dengan metode GMM. Variabel intrumental yang digunakan dalam penaksiran dengan metode GMM adalah variabel tingkat inflasi $\mathrm{t}-1$ dan $\mathrm{t}-2$; tingkat inflasi $\mathrm{t}+1$ dan $\mathrm{t}+2$, perubahan nilai tukar (lag 0 dan lag 1), pertumbuhan uang primer (lag 0 dan lag 1), dan konstanta. Indikator tingkat inflasi $\left(\pi_{i}\right)$ yang digunakan dalam penelitian ini adalah: (i) Tingkat inflasi $\mathrm{y}-\mathrm{o}-\mathrm{y}$; (ii) Tingkat inflasi IHK $(2007=100)$; (iii) Perubahan logaritma natural IHK ( $\Delta$ lnIHK) (2007= 100); (iv) Logaritma natural PDB deflator (lnPDB deflator) (2005=100); (v) Inflasi inti $(2005=100)$.

\section{HASIL DAN PEMBAHASAN}

\section{Kurva Phillips di Indonesia: Pendekatan Model Expectations Augmented Phillips Curve dan Model NKPC}

Tabel 1 menunjukkan hasil analisis regresi dengan metode OLS untuk model expectations augmented Phillips curve. Berdasarkan Tabel 1, dapat dilihat bahwa koefisien $b_{2}$ pada semua model cenderung menunjukkan nilai statistik yang tidak signifikan. Sedangkan, koefisien $b_{1}$ memiliki nilai statistik yang signifikan hanya pada 
Tabel 1. Hasil Uji Keberadaan Kurva Phillips: Pendekatan Model Expectations Augmented Phillips Curve

\begin{tabular}{|c|c|c|c|c|c|}
\hline \multirow{2}{*}{$\begin{array}{c}\text { Konstanta/ } \\
\text { Variabel } \\
\text { Independent }\end{array}$} & \multicolumn{5}{|c|}{ Variabel Dependent } \\
\hline & Inflasi y-o-y & $\begin{array}{c}\text { Inflasi IHK } \\
(2007=100)\end{array}$ & $\begin{array}{c}\Delta \operatorname{lnIHK} \\
(2007=100)\end{array}$ & $\begin{array}{c}\text { LnPDB } \\
\text { Deflator } \\
(2005=100)\end{array}$ & $\begin{array}{l}\text { Inflasi Inti } \\
(2007=100)\end{array}$ \\
\hline $\mathbf{a}$ & 2,079 & 1,999 & 0,018 & 0,214 & 1,595 \\
\hline$(t$-stat $)$ & $(1,723)$ & $(1,912)$ & $(1,847)$ & $(4,102)$ & $(3,148)$ \\
\hline$($ prob $)$ & $(0,093)$ & $(0,063)$ & $(0,072)$ & $(0,000)$ & $(0,003)$ \\
\hline$b_{1}$ & 0,765 & $-0,181$ & $-0,184$ & 0,950 & 0,368 \\
\hline$(t$-stat $)$ & $(8,192)$ & $(-1,122)$ & $(-1,141)$ & $(74,228)$ & $(2,410)$ \\
\hline (prob) & $(0,000)^{* * *}$ & $(0,268)$ & $(0,260)$ & $(0,000)^{* * *}$ & $(0,021)^{\star *}$ \\
\hline$b_{2}$ & 25,816 & 7,173 & 0,078 & $-0,114$ & 7,864 \\
\hline$(t$-stat) & $(1,077)$ & $(0,250)$ & $(0,281)$ & $(-0,744)$ & $(0,757)$ \\
\hline (prob) & $(0,288)$ & $(0,803)$ & $(0,782)$ & $(0,461)$ & $(0,453)$ \\
\hline$b_{3}$ & 0,055 & $-0,010$ & $-5,19 \mathrm{E}-05$ & 0,000405 & $-0,000589$ \\
\hline$(t$-stat) & $(0,951)$ & $(-0,152)$ & $(-0,077)$ & $(1,138)$ & $(-0,023)$ \\
\hline (prob) & $(0,347)$ & $(0,879)$ & $(0,938)$ & $(0,262)$ & $(0,981)$ \\
\hline$b_{4}$ & 0,000157 & 0,0056 & $6,50 \mathrm{E}-05$ & 0,000749 & $-0,009$ \\
\hline$(t$-stat $)$ & $(0,010)$ & $(0,330)$ & $(0,389)$ & $(4,745)$ & $(-1,481)$ \\
\hline$($ prob) & $(0,9913)$ & $(0,743)$ & $(0,698)$ & $(0,000)^{* * *}$ & $(0,147)$ \\
\hline $\mathbf{R}^{2}$ & 0,649 & 0,040 & 0,042 & 0,998 & 0,221 \\
\hline$\left(\operatorname{Adj}-R^{2}\right)$ & $(0,611)$ & $(-0,063)$ & $(-0,061)$ & $(0,998)$ & $(0,137)$ \\
\hline \multicolumn{6}{|l|}{ Asumsi Klasik: } \\
\hline JB-stat & 48,825 & 27,989 & 29,246 & 64,843 & 12,312 \\
\hline (prob) & $(0,000)$ & $(0,000)$ & $(0,000)$ & $(0,000)$ & $(0,002)$ \\
\hline \multirow[t]{2}{*}{ RESET } & 0,020 & 1,625 & 1,354 & 0,039 & 4,097 \\
\hline & $(0,887)$ & $(0,210)$ & $(0,252)$ & $(0,843)$ & $(0,050)$ \\
\hline Multikolinieritas & Bebas & Bebas & Bebas & Bebas & Bebas \\
\hline \multirow[t]{2}{*}{ B-G LM test } & 2,818 & 2,135 & 2,049 & 0,682 & 0,219 \\
\hline & $(0,073)$ & $(0,133)$ & $(0,144)$ & $(0,511)$ & $(0,804)$ \\
\hline \multirow[t]{2}{*}{ White } & 0,766 & 1,201 & 1,290 & 0,527 & 1,071 \\
\hline & $(0,693)$ & $(0,329)$ & $(0,275)$ & $(0,895)$ & $(0,422)$ \\
\hline
\end{tabular}

model yang menggunakan inflasi $\mathrm{y}-\mathrm{o}-\mathrm{y}, \ln \mathrm{PDB}$ deflator dan inflasi inti.

Hasil yang diperoleh dari model expectations augmented Phillips curve juga menunjukkan nilai statistik yang tidak signifikan untuk koefisien $b_{3}$. Sedangkan, koefisien $b_{4}$ memiliki nilai statistik yang signifikan hanya pada model yang menggunakan lnPDB deflator-yang menunjukkan bahwa harga minyak mentah (OP) memberikan pengaruh yang sangat kecil terhadap tingkat inflasi di Indonesia.

Pengujian asumsi klasik pada hasil penaksiran menunjukkan bahwa model mengalami masalah normalitas yang ditunjukkan oleh probabilitas nilai statistik JB yang signifikan. Namun, dengan menggunakan asumsi central limit theorem (CLT), maka dapat di asumsikan bahwa distribusi residual pada semua model berdistribusi normal. Hasil uji multikolinearitas, auto- kolerasi dan heteroskedastisitas menunjukkan bahwa semua model bebas dari masalah-masalah tersebut.

Masalah asumsi klasik hanya terdapat pada model yang menggunakan inflasi inti, di mana model tersebut mengalami masalah dengan asumsi linearitas. Namun, Phillips (1958: 283) pada dasarnya telah menyatakan bahwa trade-off yang ditunjukkan oleh kurva Phillips merupakan hubungan yang sangat tidak linier. Dengan demikian, masalah asumsi linearitas pada model yang menggunakan inflasi inti, sesungguhnya menunjukkan karakteristik kurva Phillips yang sebenarnya, yaitu cenderung memiliki hubungan yang tidak linier.

Kecenderungan hasil yang tidak signifikan pada model expectations augmented Phillips curve ini menunjukkan bahwa model expectations augmented Phillips curve tidak dapat memberikan 
gambaran yang jelas mengenai fenomena kurva Phillips di Indonesia. Dengan kata lain, model expectations augmented Phillips curve sudah tidak layak lagi digunakan untuk menganalisis fenomena kurva Phillips di Indonesia. Hasil yang serupa juga ditemukan oleh Saz (2011) pada perekonomian Turki dan Paloviita (2002) di euro area.

Paloviita (2002) berpendapat bahwa hasil estimasi pada model NKPC untuk euro area memiliki hasil yang jauh lebih baik jika dibandingkan dengan hasil estimasi yang dihasilkan oleh model expectations augmented Phillips curve. Bagaimana dengan hasil penaksiran dengan model NKPC untuk perekonomian Indonesia.

Tabel 2 menunjukkan hasil analisis regresi dengan metode OLS untuk model new Keynesian Phillips curve. Berdasarkan Tabel 2, dapat dilihat bahwa hasil analisis yang menggunakan model new Keynesian Phillips curve juga memberikan hasil yang sama seperti model expectations augmented Phillips curve. Koefisien $\gamma_{2}$ pada semua model, cenderung memiliki nilai statistik yang tidak signifikan.

Pengujian asumsi klasik yang disajikan pada Tabel 2, secara umum menunjukkan bahwa masing-masing model tidak memiliki masalah dengan asumsi klasik. Dengan demikian, sama seperti hasil pada model expectations augmented Phillips curve-hasil analisis yang ditunjukkan oleh model new Keynesian Phillips curve juga tidak dapat memberikan gambaran yang jelas

Tabel 2. Hasil Uji Keberadaan Kurva Phillips: Pendekatan Model New Keynesian Phillips Curve

\begin{tabular}{|c|c|c|c|c|c|}
\hline \multirow{2}{*}{$\begin{array}{l}\text { Konstanta/ } \\
\text { Variabel } \\
\text { Independent }\end{array}$} & \multicolumn{5}{|c|}{ Variabel Dependent } \\
\hline & Inflasi y-0-y & $\begin{array}{c}\text { Inflasi IHK } \\
(2007=100)\end{array}$ & $\begin{array}{l}\Delta \text { LnIHK } \\
(2007=100)\end{array}$ & $\begin{array}{c}\text { LnPDB Deflator } \\
(2005=100)\end{array}$ & $\begin{array}{l}\text { Inflasi Inti } \\
(2007=100)\end{array}$ \\
\hline $\begin{array}{c}a \\
(t-s t a t) \\
(\text { prob })\end{array}$ & $\begin{array}{l}1,150 \\
(0,920) \\
(0,363)\end{array}$ & $\begin{array}{c}2,136 \\
(2,076) \\
(0,044)\end{array}$ & $\begin{array}{c}0,020 \\
(2,020) \\
(0,050)\end{array}$ & $\begin{array}{c}-0,053 \\
(-1,747) \\
(0,088)\end{array}$ & $\begin{array}{c}1,298 \\
(2,499) \\
(0,017)\end{array}$ \\
\hline $\begin{array}{c}\gamma_{1} \\
(t-s t a t) \\
(\text { prob })\end{array}$ & $\begin{array}{c}0,855 \\
(8,216) \\
(0,000)^{* * *}\end{array}$ & $\begin{array}{c}-0,214 \\
(-1,291) \\
(0,204)\end{array}$ & $\begin{array}{c}-0,221 \\
(-1,326) \\
(0,192)\end{array}$ & $\begin{array}{c}1,025 \\
(59,760) \\
(0,000)^{* * *}\end{array}$ & $\begin{array}{c}0,458 \\
(2,748) \\
(0,009)^{* * *}\end{array}$ \\
\hline $\begin{array}{c}\gamma_{2} \\
(t-s t a t) \\
(\text { prob })\end{array}$ & $\begin{array}{c}-10,009 \\
(-0,390) \\
(0,698)\end{array}$ & $\begin{array}{l}17,538 \\
(0,594) \\
(0,555)\end{array}$ & $\begin{array}{c}0,187 \\
(0,646) \\
(0,522)\end{array}$ & $\begin{array}{l}0,037 \\
(0,451) \\
(0,654)\end{array}$ & $\begin{array}{c}-1,279 \\
(-0,121) \\
(0,903)\end{array}$ \\
\hline $\begin{array}{c}\gamma_{3} \\
(t-s t a t) \\
(\text { prob })\end{array}$ & $\begin{array}{c}-0,085 \\
(-1,415) \\
(0,165)\end{array}$ & $\begin{array}{c}-0,015 \\
(-0,227) \\
(0,821)\end{array}$ & $\begin{array}{c}-0,000111 \\
(-0,167) \\
(0,867)\end{array}$ & $\begin{array}{c}-0,000272 \\
(-1,497) \\
(0,142)\end{array}$ & $\begin{array}{c}-0,037 \\
(-1,420) \\
(0,163)\end{array}$ \\
\hline $\begin{array}{c}\gamma_{4} \\
(\text { t-stat }) \\
(\text { prob) }\end{array}$ & $\begin{array}{c}-0,000457 \\
(-0,030) \\
(0,975)\end{array}$ & $\begin{array}{c}0,004 \\
(0,261) \\
(0,795)\end{array}$ & $\begin{array}{c}5,26 \mathrm{E}-05 \\
(0,319) \\
(0,750)\end{array}$ & $\begin{array}{c}-0,000188 \\
(-2,065) \\
(0,045)\end{array}$ & $\begin{array}{c}-0,006 \\
(-0,972) \\
(0,337)\end{array}$ \\
\hline $\begin{array}{c}R^{2} \\
\left(\operatorname{Adj}-R^{2}\right)\end{array}$ & $\begin{array}{c}0,651 \\
(0,613)\end{array}$ & $\begin{array}{c}0,048 \\
(-0,05)\end{array}$ & $\begin{array}{c}0,051 \\
(-0,051)\end{array}$ & $\begin{array}{c}0,997 \\
(0,997)\end{array}$ & $\begin{array}{c}0,234 \\
(0,152)\end{array}$ \\
\hline \multicolumn{6}{|l|}{ Asumsi Klasik: } \\
\hline $\begin{array}{c}\text { JB-stat } \\
\text { (prob) }\end{array}$ & $\begin{array}{c}9,871 \\
(0,007)\end{array}$ & $\begin{array}{l}24,914 \\
(0.000)\end{array}$ & $\begin{array}{l}23,521 \\
(0,000)\end{array}$ & $\begin{array}{l}11,811 \\
(0,002)\end{array}$ & $\begin{array}{c}5,383 \\
(0,067)\end{array}$ \\
\hline RESET & $\begin{array}{c}0,996 \\
(0,324)\end{array}$ & $\begin{array}{c}0,409 \\
(0,526)\end{array}$ & $\begin{array}{c}0,539 \\
(0,467)\end{array}$ & $\begin{array}{c}0,897 \\
(0,349)\end{array}$ & $\begin{array}{c}0,060 \\
(0,806)\end{array}$ \\
\hline Multikolinieritas & Bebas & Bebas & Bebas & Bebas & Bebas \\
\hline B-G LM test & $\begin{array}{c}1,560 \\
(0,224)\end{array}$ & $\begin{array}{c}0,022 \\
(0,978)\end{array}$ & $\begin{array}{c}0,026 \\
(0,973)\end{array}$ & $\begin{array}{c}0,216 \\
(0,806)\end{array}$ & $\begin{array}{c}0,549 \\
(0,582)\end{array}$ \\
\hline White/ARCH & $\begin{array}{c}0,657 \\
(0,793)\end{array}$ & $\begin{array}{r}0,008^{a} \\
(0,925)\end{array}$ & $\begin{array}{l}0,021^{\mathrm{a}} \\
(0,884)\end{array}$ & $\begin{array}{c}0,821 \\
(0,641)\end{array}$ & $\begin{array}{c}1,335 \\
(0,251)\end{array}$ \\
\hline
\end{tabular}

Keterangan: *** merupakan tingkat signifikan pada tingkat kepercayaan 1\%. Angka dalam kolom RESET, B-G LM test dan White/ARCH, masing-masing merupakan F-stat dan prob-F. Untuk uji multikolinieritas, apabila korelasi parsial antara variabel independent $<0,85$, maka dapat dikatakan bahwa model bebas dari gejala multikolinieritas. "a" merupakan pengujian heteroskedastisitas yang menggunakan uji ARCH. 
mengenai fenomena trade-off antara tingkat inflasi dan output gap di perekonomian Indonesia.

Hal tersebut ditunjukkan oleh ketidakmampuan model expectations augmented Phillips curve dan new Keynesian Phillips curve dalam menghasilkan nilai statistik $b_{2}$ dan $\gamma_{2}$ yang signifikan. Ketidakmampuan model new Keynesian Phillips curve dalam menjelaskan fenomena kurva Phillips di Indonesia didukung oleh pendapat yang dikemukakan oleh Ball (1994a, 1994b) dan Fuhrer dan Moore (1995) mengenai kelemahan new Keynesian Phillips curve.

Ball (1994a, 1994b) menunjukkan suatu ketidakkonsistenan antara dampak disinflation yang ditunjukkan dalam model new Keynesian Phillips curve dan dampak disinflation pada perekonomian riil secara aktual. Menurut Ball (1994b), secara aktual, kondisi disinflation dapat mengakibatkan resesi pada perekonomian yang ditandai dengan penurunan output agregat. Namun dalam model, Ball (1994a) menemukan bahwa kondisi disinflation yang dapat dipercaya (credible) dapat menghasilkan suatu boom pada perekonomian.

Ketidakkonsistenan model new Keynesian Phillips curve disebabkan karena penentuan harga dalam model bersifat forward-looking $(t+1)$. Sehingga, kebijakan disinflation akan menurunkan ukuran kenaikan harga yang digunakan oleh agen-agen ekonomi bahkan sebelum terjadinya perlambatan penawaran uang. Akibatnya, keseimbangan uang riil (real money balance) akan meningkat-yang pada akhirnya akan menyebabkan peningkatan output. Ketidakkonsistenan ini menyebabkan ketidakstabilan model new Keynesian Phillips curve dalam menjelaskan fenomena trade-off antara tingkat inflasi dan tingkat output.

Sedangkan, Fuhrer dan Moore (1995) berpendapat bahwa model new Keynesian Phillips curve tidak mampu menunjukkan derajat yang tinggi dari inflation persistence. Dalam model new Keynesian Phillips curve-tingkat harga menyesuaikan secara perlahan terhadap goncangan yang terjadi di perekonomian, sedangkan tingkat inflasi dapat menyesuaikan dengan cepat apabila terjadi perubahan harga.

Menurut Fuhrer dan Moore (1995), fakta yang ditunjukkan pada model tersebut bertentangan dengan fakta empiris pada data. Data menunjukkan bahwa tingkat inflasi merupakan variabel yang sangat persistent. Oleh karena itu, Fuhrer dan Moore (1995) berpendapat bahwa tingkat inflasi juga memiliki suatu efek kelambanan (inertia) dalam hal waktu yang dibutuhkan untuk proses penyesuaian akibat adanya suatu goncangan dalam perekonomian. Menurut Fuhrer dan Moore, kelemahan pada model new Keynesian Phillips curve adalah model tersebut tidak mampu menunjukkan unsur kelambanan pada tingkat inflasi sehingga model tidak mampu untuk menjelaskan fenomena trade-off pada kurva Phillips.

\section{Eksistensi Kurva Phillips di Indonesia: Pendekatan Hybrid Model dari NKPC}

Terkait dengan kritik-kritik terhadap model new Keynesian Phillips curve yang disampaikan oleh Ball dan Fuhrer dan Moore, Gali dan Gertler (1999) mengembangkan hybrid model dari NKPC. Hybrid model ini mencoba memasukkan efek kelambanan inflasi dalam model NKPC dengan cara menggunakan tingkat inflasi secara backward-looking ( $\mathrm{t}-1)$ sebagai rule of thumb dalam menentukan harga.

Tabel 3 menyajikan hasil penaksiran hybrid model dari new Keynesian Phillips curve dengan menggunakan metode GMM. Menurut Solikin (2004), metode GMM tidak menggunakan $\mathrm{R}^{2}$ sebagai statistik standar dalam mengevaluasi baik tidaknya suatu model. Metode GMM menggunakan nilai $j$-statistik (j-stat) untuk melihat validitas penggunaan variabel instrumental yang jumlahnya dapat melebihi jumlah parameter yang ditaksir. Berdasarkan nilai $j$-stat yang disajikan pada Tabel 3, dapat disimpulkan bahwa penggunaan variabel instrumental pada masing-masing model adalah valid.

Berdasarkan hasil penaksiran pada Tabel 3, dapat dilihat bahwa hasil penaksiran yang menggunakan inflasi y-o-y dan dengan lnygap $p_{t}$ memiliki koefisien parameter backward $\left(\delta_{1}\right)$ dan forward $\left(\delta_{2}\right)$ yang signifikan pada tingkat kepercayaan $1 \%$. Namun, koefisien parameter output gap $\left(\delta_{3}\right)$ memiliki nilai statistik yang tidak signifikan.

Penaksiran yang menggunakan inflasi y-o-y dengan lnygapt-1 memiliki koefisien para- 
Tabel 3. Hasil Uji Keberadaan dan Pola Pembentukan Ekspektasi pada Hybrid Model New Keynesian Phillips Curve

\begin{tabular}{|c|c|c|c|c|c|c|}
\hline \multirow{2}{*}{$\begin{array}{c}\text { Variabel } \\
\text { Dependent }\end{array}$} & \multirow{2}{*}{ Model } & \multicolumn{5}{|c|}{ Konstanta/Variabel Independent/J-stat } \\
\hline & & $a$ & $\delta_{1}$ & $\delta_{2}$ & $\delta_{3}$ & j-stat \\
\hline \multirow{3}{*}{ Inflasi y-o-y } & $\ln y_{\text {gap }_{t}}$ & $\begin{array}{c}-0,126 \\
(-0,332)\end{array}$ & $\begin{array}{c}0,486 \\
(10,887)^{* * *}\end{array}$ & $\begin{array}{c}0,531 \\
(8,121)^{\star * *}\end{array}$ & $\begin{array}{l}57,434 \\
(1,075)\end{array}$ & 0,085 \\
\hline & $\ln y_{\mathrm{gap}}{ }_{t-1}$ & $\begin{array}{c}0,088 \\
(0,292)\end{array}$ & $\begin{array}{c}0,484 \\
(13,425)^{\star * *}\end{array}$ & $\begin{array}{c}0,478 \\
(9,799)^{\star * *}\end{array}$ & $\begin{array}{c}-29,272 \\
(-2,141)^{\star *}\end{array}$ & 0,147 \\
\hline & $\ln y_{\mathrm{gap}}{ }_{t+1}$ & $\begin{array}{c}0,092 \\
(0,299)\end{array}$ & $\begin{array}{c}0,469 \\
(11,925)^{* * *}\end{array}$ & $\begin{array}{c}0,502 \\
(10,113)^{* * *}\end{array}$ & $\begin{array}{l}18,902 \\
(1,350)\end{array}$ & 0,124 \\
\hline \multirow{3}{*}{$\Delta$ LnIHK } & $\ln y_{\text {gap }_{t}}$ & $\begin{array}{c}0,020 \\
(7,838)\end{array}$ & $\begin{array}{c}-0,010 \\
(-1,309)\end{array}$ & $\begin{array}{c}0,005 \\
(0,423)\end{array}$ & $\begin{array}{c}-0,450 \\
(-2,449)^{\star *}\end{array}$ & 0,063 \\
\hline & $\ln y_{\text {gap }_{t-1}}$ & $\begin{array}{c}0,018 \\
(7,637)\end{array}$ & $\begin{array}{c}-0,026 \\
(-2,828)^{\star * *}\end{array}$ & $\begin{array}{c}-0,035 \\
(-1,727)^{*}\end{array}$ & $\begin{array}{c}0,457 \\
(2,741)^{* * *}\end{array}$ & 0,074 \\
\hline & $\ln y_{\mathrm{gap}_{t+1}}$ & $\begin{array}{c}0,016 \\
(7,583)\end{array}$ & $\begin{array}{c}-0,015 \\
(-1,708)^{*}\end{array}$ & $\begin{array}{c}-0,009 \\
(-3,413)^{\star * *}\end{array}$ & $\begin{array}{c}0,199 \\
(2,214)^{* *}\end{array}$ & 0,142 \\
\hline \multirow{3}{*}{$\begin{array}{l}\text { InPDB } \\
\text { Deflator }\end{array}$} & $\ln y_{\text {gap }_{t}}$ & $\begin{array}{c}-0,005 \\
(-0,454)\end{array}$ & $\begin{array}{c}0,531 \\
(8,420)^{* * *}\end{array}$ & $\begin{array}{c}0,471 \\
(7,583)^{\star * *}\end{array}$ & $\begin{array}{c}0,417 \\
(1,314)\end{array}$ & 0,106 \\
\hline & $\ln y_{\text {gap }_{t-1}}$ & $\begin{array}{c}0,013 \\
(1,278)\end{array}$ & $\begin{array}{c}0,463 \\
(9,163)^{* * *}\end{array}$ & $\begin{array}{c}0,534 \\
(10,817)^{* * *}\end{array}$ & $\begin{array}{c}-0,260 \\
(-2,772)^{* * *}\end{array}$ & 0,065 \\
\hline & $\ln y_{\mathrm{gap}_{t+1}}$ & $\begin{array}{c}0,011 \\
(0,939)\end{array}$ & $\begin{array}{c}0,556 \\
(11,596)^{* * *}\end{array}$ & $\begin{array}{c}0,442 \\
(9,312)^{* * *}\end{array}$ & $\begin{array}{c}0,273 \\
(2,579)^{* * *}\end{array}$ & 0,098 \\
\hline \multirow{3}{*}{ Inflasi Inti } & $\ln y_{\text {gap }_{t}}$ & $\begin{array}{c}0,001 \\
(0,007)\end{array}$ & $\begin{array}{c}0,375 \\
(2,959)^{* * *}\end{array}$ & $\begin{array}{c}0,574 \\
(4,754)^{\star * * *}\end{array}$ & $\begin{array}{c}-39,723 \\
(-1,989)^{*}\end{array}$ & 0,109 \\
\hline & $\ln y_{\operatorname{gap}_{t-1}}$ & $\begin{array}{c}0,089 \\
(0,614)\end{array}$ & $\begin{array}{c}0,528 \\
(6,442)^{* * *}\end{array}$ & $\begin{array}{c}0,369 \\
(4,755)^{* * *}\end{array}$ & $\begin{array}{c}14,606 \\
(2,457)^{* *}\end{array}$ & 0,115 \\
\hline & $\ln y_{\mathrm{gap}}{ }_{t+1}$ & $\begin{array}{c}-2,659 \\
(-0,551)\end{array}$ & $\begin{array}{c}0,758 \\
(6,583)^{\star * *}\end{array}$ & $\begin{array}{c}0,438 \\
(2,183)^{\star *}\end{array}$ & $\begin{array}{c}0,514 \\
(0,537)\end{array}$ & 0,127 \\
\hline
\end{tabular}

Keterangan: * ${ }^{* *},{ }^{* * *}$ masing-masing merupakan tingkat signifikan pada tingkat kepercayaan 10\%, 5\%, 1\%. Angka dalam kurung di bawah masing-masing parameter merupakan nilai $t$-statistik. Dengan tingkat kepercayaan 5\% (95\%), apabila nilai $j$ stat $>$ tabel distribusi chi-square $\left(\chi_{k-l}^{2}\right)$-maka hipotesis null yang menyatakan bahwa model valid ditolak, sedangkan hipotesis alternatif yang menyatakan model tidak valid diterima. Sebaliknya, apabila nilai $j$-stat $<$ tabel distribusi chi-square $\left(\chi_{k-l}^{2}\right)-$ maka hipotesis null yang menyatakan bahwa model valid diterima, sedangkan hipotesis alternatif yang menyatakan model tidak valid ditolak.

meter backward $(0,484)$ dan forward $(0,478)$ yang signifikan dan keduanya memiliki nilai positif-serta memiliki koefisien parameter output gap yang signifikan dengan nilai koefisien output gap yang negatif. Namun, koefisien output gap yang signifikan ini memiliki nilai yang terlalu besar $(-29,272)$, di mana penelitian terdahulu yang dilakukan oleh Solikin (2004) dan Sarwohadi (2009) memperoleh nilai koefisien output gap yang hanya berkisar 0,2 sampai dengan 0,6 .

Penaksiran yang menggunakan inflasi $\mathrm{y}-\mathrm{o}-\mathrm{y}$ dengan lnygap $\mathrm{p}_{\mathrm{t}+1}$ memiliki hasil penaksiran yang serupa dengan penaksiran inflasi yo-y dengan lnygap. Selanjutnya, hasil penaksiran yang menggunakan $\Delta$ lnIHK dengan lnygap $_{\mathrm{t}}$ memiliki koefisien parameter backward $\left(\delta_{1}\right)$ dan forward $\left(\delta_{2}\right)$ yang tidak signifikan dan nilai koefisien output gap yang negatif dan signifikan (-0,450). Namun, hasil penaksiran ini belum dapat menghasilkan hasil yang baik karena model belum dapat memberikan koefisien parameter $\delta_{1}$ dan $\delta_{2}$ yang signifikan secara bersama-sama.

Hasil penaksiran yang menggunakan $\Delta$ lnIHK dengan lnygapt-1 menunjukkan bahwa koefisien $\delta_{1}, \delta_{2}$, dan $\delta_{3}$ memiliki nilai $t$-statistik yang signifikan secara statistik-di mana, masing-masing koefisien signifikan pada tingkat kepercayaan $1 \%, 10 \%$ dan $1 \%$. Koefisien $\delta_{1}$ dan $\delta_{2}$ memiliki nilai yang negatif, yaitu $-0,026$ dan 0,035 yang menunjukkan bahwa adanya ketidaksesuaian antara ekspektasi inflasi baik secara backward dan forward dengan inflasi secara aktual. Koefisien output gap memiliki nilai positif $(0,475)$ yang menunjukkan bahwa fenomena kurva Phillips eksis di perekonomian Indonesia. 
Selanjutnya, hasil penaksiran yang menggunakan $\Delta \operatorname{lnIHK}$ dengan lnygap $\mathrm{p}_{t+1}$ juga menunjukkan bahwa koefisien $\delta_{1}, \delta_{2}$, dan $\delta_{3}$ memiliki nilai $t$-statistik yang signifikan secara statistik-di mana, masing-masing koefisien signifikan pada tingkat kepercayaan $10 \%, 1 \%$ dan $5 \%$. Koefisien $\delta_{1}$ dan $\delta_{2}$ juga memiliki nilai yang negatif dengan nilai koefisien output gap yang lebih rendah $(0,199)$.

Hasil penaksiran yang menggunakan

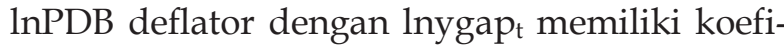
sien $\delta_{1}$ dan $\delta_{2}$ yang signifikan dan positif, namun memiliki koefisien $\delta_{3}$ yang tidak signifikan. Hasil penaksiran yang menggunakan lnPDB deflator dengan lnygap $\mathrm{t}_{-1}$ menunjukkan hasil penaksiran yang baik, di mana, baik koefisien $\delta_{1}, \delta_{2}$, dan $\delta_{3}$ memiliki nilai $t$-statistik yang signifikan pada tingkat kepercayaan $1 \%$. Koefisien $\delta_{1}$ dan $\delta_{2}$ memiliki nilai positif, yaitu 0,463 dan 0,534 yang menunjukkan adanya kesesuaian antara ekspektasi inflasi baik secara backward dan forward dengan inflasi aktual. Sedangkan koefisien output gap memiliki nilai yang negatif $(-0,260)$ yang menunjukkan bahwa fenomena kurva Phillips tidak eksis di perekonomian Indonesia.

Hasil penaksiran yang menggunakan $\ln P D B$ deflator dengan lnygap ${ }_{t+1}$ juga menunjukkan hasil penaksiran yang baik-di mana, baik koefisien $\delta_{1}, \delta_{2}$, dan $\delta_{3}$ memiliki nilai $t$-statistik yang signifikan pada tingkat kepercayaan $1 \%$. Berbeda dengan hasil penaksiran sebelumnya, hasil penaksiran yang menggunakan $\ln \mathrm{PDB}$ deflator dengan lnygap $\mathrm{t}_{\mathrm{t}+1}$ ini memiliki koefisien $\delta_{1}, \delta_{2}$, dan $\delta_{3}$ yang positif. Nilai koefisien output gap yang positif $(0,273)$ menunjukkan bahwa fenomena kurva Phillips eksis di perekonomian Indonesia.

Hasil penaksiran yang menggunakan inflasi inti dengan lnygap $p_{t}$ memiliki koefisien $\delta_{1}, \delta_{2}$, dan $\delta_{3}$ yang signifikan secara statistik-di mana, koefisien $\delta_{1}$ dan $\delta_{2}$ memiliki nilai positif, sedangkan koefisien output gap memiliki nilai negatif dan memiliki nilai yang besar $(-39,723)$. Hasil penaksiran yang menggunakan inflasi inti dengan lnygap $\mathrm{t}_{\mathrm{t}-1}$ juga memiliki koefisien $\delta_{1}, \delta_{2}$, dan $\delta_{3}$ yang signifikan secara statistik-di mana, koefisien $\delta_{1}, \delta_{2}$, dan $\delta_{3}$ masing-masing memiliki nilai yang positif. Selanjutnya, hasil penaksiran yang menggunakan inflasi inti dan lnygap $_{t+1}$ memiliki koefisien $\delta_{1}$ dan $\delta_{2}$ yang signifikan dan positif, namun memiliki koefisien $\delta_{3}$ yang tidak signifikan.

Hasil penaksiran pada hybrid model dari NKPC menunjukkan hasil penaksiran yang beragam dari setiap pendekatan inflasi dan model yang digunakan. Namun, terdapat tiga kencenderungan yang menjadi fenomena yang menarik, yaitu (i) pada saat koefisien backward $\left(\delta_{1}\right)$ dan forward $\left(\delta_{2}\right)$ memiliki nilai yang positif-maka koefisien output gap cenderung menunjukkan nilai yang negatif. Fenomena ini menunjukkan bahwa pada saat ekspektasi inflasi sesuai dengan inflasi secara aktual, maka fenomena kurva Phillips menjadi tidak eksis.

Sebaliknya, (ii) pada saat koefisien backward dan forward memiliki nilai yang negatif-koefisien output gap cenderung memiliki nilai positif. Fenomena ini menunjukkan bahwa adanya ketidaksesuaian antara ekspektasi inflasi dan inflasi aktual yang kemudian menyebabkan eksisnya fenomena kurva Phillips. Fenomena (iii) adalah pada saat koefisien backward $\left(\delta_{1}\right)$ dan forward $\left(\delta_{2}\right)$ memiliki nilai yang positif-maka koefisien output gap cenderung menunjukkan nilai yang positif. Fenomena ini menunjukkan bahwa meskipun ekspektasi inflasi sesuai dengan inflasi secara aktual, fenomena kurva Phillips akan tetap eksis. Dengan demikian, manakah hasil penaksiran yang sesuai dan menggambarkan kondisi perekonomian Indonesia yang sebenarnya.

\section{Kurva Phillips dan Kebijakan Moneter}

Friedman (1958) berpendapat bahwa "fenomena trade-off yang ditunjukkan oleh kurva Phillips hanya akan terjadi secara sementara (jangka pendek) dan tidak akan pernah terjadi secara permanen (jangka panjang), di mana, trade-off yang terjadi secara sementara tersebut berasal dari inflasi yang tidak terantisipasi."

Phelps (1968) mengemukakan bahwa "dalam hal persentase kenaikan harga, pergeseran satu titik ke atas yang terjadi sebagai akibat dari adanya kenaikan harga, akan sesuai dengan kenaikan setiap satu titik dari persentase kenaikan harga yang diharapkan akan menyebabkan keseimbangan tingkat pengangguran tidak tergantung pada tingkat inflasi."

Berdasarkan argumen yang dikemukakan 
oleh Friedman (1958) dan Phelps (1968), dapat disimpulkan bahwa fenomena kurva Phillips terjadi sebagai akibat dari adanya kegagalan ekspektasi masyarakat terhadap tingkat inflasi yang terjadi secara aktual. Selain itu, apabila kenaikan harga aktual sama dengan kenaikan harga yang diharapkan, maka hal tersebut akan menyebabkan tidak eksisnya fenomena kurva Phillips.

Memperluas analisis ke arah sifat dari kebijakan moneter yang diambil oleh bank sentral (rule atau discretion), Kydland dan Prescott (1977) berpendapat bahwa "dengan asumsi rational expectationss, suatu kebijakan moneter yang mengikuti rule akan menyebabkan ekspektasi inflasi sama dengan tingkat inflasi yang diekspektasi $\left(\pi_{t}^{e}=E \pi\right)$." Sehingga, hasil kebijakan moneter yang mengikuti rule akan memperoleh keseimbangan yang optimal. Kydland dan Prescoot berpendapat bahwa pada keseimbangan optimal, fenomena kurva Phillips menjadi tidak eksis.

Sebaliknya, sebuah discretionary policy-di mana para pengambil kebijakan memilih aksi terbaik pada setiap situasi-tidak mampu untuk memaksimalkan social objective function dari agen-agen ekonomi. Dengan kata lain, kebijakan moneter yang bersifat discretion tidak akan mampu menghasilkan suatu hasil yang optimal dan cenderung akan menyebabkan eksisnya fenomena kurva Phillips.
Argumen-argumen yang dikemukakan oleh Friedman, Phelps serta Kydland dan Prescott menunjukkan adanya keterkaitan antara sifat kebijakan moneter (rule atau discretion) dan eksistensi fenomena kurva Phillips. Mengacu pada pendapat yang dikemukakan oleh Friedman dan Phelps, tampak bahwa fenomena (i) dan (ii) yang diperoleh dari hasil penaksiran hybrid model dari NKPC pada pembahasan sebelumnya telah sesuai dengan konsep teori yang dikemukakan oleh Friedman dan Phelps. Dengan demikian, manakah hasil yang sesuai dengan kondisi perekonomian Indonesia. Untuk menjawab pertanyaan tersebut, terlebih dahulu harus diketahui bagaimana sifat kebijakan moneter di Indonesia, 2000Q1-2010Q3.

Rahutami (1994) menyatakan bahwa pada periode 1970-1991, kebijakan moneter di Indonesia cenderung kearah kebijakan moneter yang discretion. Kebijakan moneter yang discretion terlihat dari pertumbuhan Jumlah Uang Beredar (JUB) yang terus berfluktuasi pada periode 1970-1991. Rahutami (1994) berpendapat bahwa metode yang paling sederhana untuk melihat sifat kebijakan moneter di Indonesia, 2000Q1-2010Q3 adalah dengan menggunakan velositas peredaran uang.

Gambar 1 menunjukkan velositas peredaran uang di Indonesia, 2000Q1-2010Q3. Berdasarkan Gambar 1, velositas peredaran uang di Indonesia menunjukkan tingkat fluktuasi yang

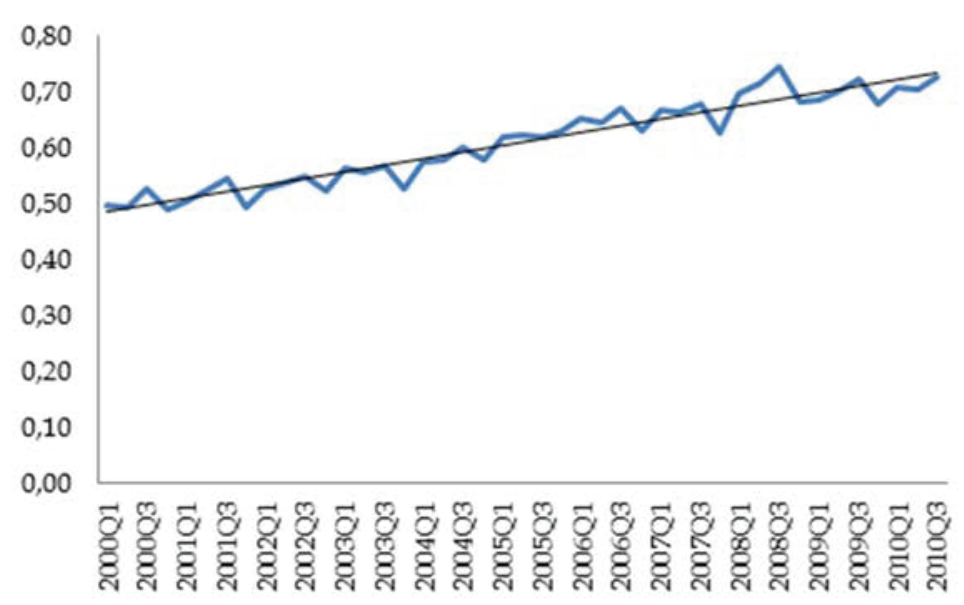

- Velositas Linear(Velositas)

Sumber: Bank Indonesia (Data diolah)

Gambar 1. Velositas Peredaran Uang di Indonesia, 2000Q1-2010Q3 
sangat beragam. Tingkat fluktuasi velositas peredaran uang yang beragam ini mengindikasikan adanya bias antara kebijakan yang diambil dan respon agen-agen ekonomi dalam menanggapi kebijakan yang diambil tersebut. Menurut Rahutami (2004), velositas yang berfluktuasi menunjukkan bahwa variabel JUB bukan merupakan faktor utama yang menentukan kegiatan ekonomi.

Dengan demikian, apabila JUB bukan merupakan faktor utama penentu kegiatan ekonomi, maka dapat dikatakan bahwa sektor riil memiliki pengaruh yang cukup kuat-sehingga menyebabkan Bank Indonesia (BI)) memilih tingkat pertumbuhan JUB yang beragam untuk menyesuaikan kebijakannya dengan kondisi dan kebutuhan sektor riil. Hal ini menunjukkan bahwa kebijakan yang di ambil oleh BI selama periode 2000Q1-2010Q3 masih cenderung bersifat kebijakan yang discretion. Temuan ini juga didukung oleh pendapat Solikin (2008) yang juga menekankan bahwa penerapan respon kebijakan moneter di Indonesia saat ini masih cenderung kepada penggunaan pola kebijakan yang discretion.

Dengan demikian, hasil penaksiran dari hybrid model dari NKPC yang sesuai dengan kondisi perekonomian Indonesia, 2000Q12010Q3 dengan kebijakan moneter yang bersifat discretion adalah hasil penaksiran yang menggunakan pendekatan $\Delta$ lnIHK dengan lnygap $_{\mathrm{t}-1}$ dan lnygap $\mathrm{t}_{\mathrm{t}+1}$. Hasil penaksiran tersebut menunjukkan adanya ketidaksesuaian antara ekspektasi inflasi dan inflasi aktual yang terjadi sebagai akibat dari pola kebijakan moneter yang diterapkan di Indonesia masih bersifat kebijakan yang discretion-yang pada akhirnya menyebabkan eksisnya fenomena kurva Phillips di Indonesia pada periode 2000Q1-2010Q3.

\section{SIMPULAN}

Eksistensi dari fenomena kurva Phillips di Indonesia cenderung disebabkan oleh adanya ketidaksesuaian antara ekspektasi inflasi dan inflasi aktual daripada oleh variabel-variabel guncangan seperti perubahan nilai tukar atau harga minyak mentah dunia. Untuk itu, jika sasaran kebijakan moneter yang ingin dicapai oleh Bank Indonesia adalah untuk mencapai tingkat inflasi yang rendah dan pertumbuhan ekonomi yang tinggi, maka upaya yang perlu dilakukan adalah menciptakan kebijakan moneter yang lebih kredibel dan konsisten yang sesuai dengan rule. Hal tersebut dilakukan untuk mengurangi biaya ketidakpastian dalam pelaksanaan kebijakan moneter yang bersifat discretion.

\section{DAFTAR PUSTAKA}

Amir, Amri. 2008. Pengaruh Inflasi dan Pertumbuhan Ekonomi terhadap Pengangguran di Indonesia. http:amriamir.files.wordpress. com/inflasi-dan-pengangguran-diindonesia-1.pdf. Diakses 10 Januari 2011.

Ball, Laurence dan Mankiw, N.G. 2002. The NAIRU in Theory and Practice. The Journal of Economic Perspectives, 16(4): 115-136.

Ball, Laurence. 1994a. Credible Disinflation with Staggered Price Setting. American Economic Review, 84: 282-289.

Ball, Laurence. 1994b. What Determines the Sacrifice Ratio?. Monetary Policy. USA: The University of Chicago Press.

Mankiw, N. G. (editor). 1994. Monetary Policy. Chicago: University of Chicago Press.

Case dan Fair. 2007. Principles of Economics, 8 edition. New Jersey: Pearson Education, Inc.

Clarida, Richard, et.al. 1999. The Science of Monetary Policy: A New Keynesian Perspective. Journal of Economic Literature, 27 (4): 1661-1707.

Dornbusch, Rudiger, et.al. 2008. Macroeconomics, Tenth Edition. Singapore: McGraw-Hill.

Friedman, Milton. 1968. The Role of Monetary Policy. American Economic Review, 58(1): 117.

Fuhrer, Jeff dan Moore, George. 1995. Inflation Persistence. The Quarterly Journal of Economics, 110(1): 127-159.

Gali, Jordi dan Gertler, Mark. 1999. Inflation Dynamics: A Structural Econometric Ana- 
lysis. Journal of Monetary Economics, 44: 195-222.

Ika, A.P. 2008. Analisis Kurva Phillips dan Hukum Okun di Indonesia: 1983-2006. Skripsi. Fakultas Ekonomika dan Bisnis Universitas Gadjah Mada, Yogyakarta.

Kydland, Finn E. dan Prescott, Edward C. 1977. Rules Rather than Discretion: The Inconsistency of Optimal Plans, The Journal of Political Economy, 85(3): 473-492.

Paloviita, Maritta. 2002. Inflation Dynamics in the Euro Area and the Role of Expectationss. Bank of Finland Discussion Papers, 20: 1-24.

Phelps, Edmund S. 1968. Money-Wage Dynamics and Labor-Market Equilibrium. The Journal of Political Economy, 76(4): 678-711.

Phillips, A.W. 1958. The Relation Between Unemployment and the Rate of Change of Money Wage Rates in the United Kingdom, 1861-1957. Economica, 25(100): 283299.

Puzon, Klarizze Anne M. 2009. The Inflation Dynamics of the ASEAN-4: A Case Study of the Phillips Curve Relationship. Journal of American Science, 5(1): 55-57.

Rahutami, A.I. 1994. Kebijakan Moneter Rules atau Discretion. Jurnal Ekonomi dan Bisnis Indonesia, Volume 9.
Roberts, John M. 1995. New Keynesian Economics and the Phillips Curve. Journal of Money, Credit and Banking, 27(4): 975-984.

Samuelson, P.A dan Solow, Robert M. 1960. Analytical Aspects of Anti-Inflation Policy. American Economic Review, 50(2): 177194.

Sarwohadi, Sanjoyo. 2009. Model New Keynesian Small Macroeconomic untuk Kebijakan Moneter di Indonesia. Perencanaan Pembangunan, Edisi 02/Tahun xv/2009.

Saz, Gökhan. 2011. The Turkish Phillips Curve Experience and the New Keynesian Phillips Curve: A Conceptualization and Application of a Novel Measure for Marginal Costs. International Research Journal of Finance and Economics, Issues 63.

Solikin. 2004. Kurva Phillips dan Perubahan Struktural di Indonesia: Keberadaan, Pola Pembentukan Ekspektasi, dan Linearitas, Buletin Ekonomi Moneter dan Perbankan, 6(4): 42-75.

Solikin. 2008. Respon Kebijakan Moneter yang Optimal di Indonesia: The State-Contingent Rule?, Buletin Ekonomi Moneter dan Perbankan, 10(4): 303-336.

Sri Mulyati. 2009. Analisis Hubungan Inflasi dan Pengangguran di Indonesia Periode 19852008: Pendekatan Kurva Phillips. Skripsi. IPB, Bogor. 